\title{
REFLECTIONS ON DEVELOPING TRENDS IN THE LAW OF STUDENT RIGHTS *
}

\section{STEPHEN R. GOLDSTEIN $\dagger$}

This past year has witnessed a spurt of interest in the law concerning rights of public school students, an interest coinciding with, and possibly attributable to, the increasing number of judicial decisions in favor of students' "rights" vis-à-vis school administrations. Rather than attempt to enumerate and dissect the myriad of recent decisions, this Paper presents in a general manner my views on developing judicial trends in this area. First, however, it may be well to place the current developments in historical perspective. Today's growing judicial involvement in the field of public education is not unprecedented. In the late nineteenth century and the early part of this century, a regular pattern of decisions developed in which school administration rules and regulations that went beyond the scope of school power as the courts saw it were held invalid.

These cases were consistent with the prevailing judicial skepticism of any government interference with "rights" of citizens, a philosophy most dramatically revealed in the economic substantive due process cases. Indeed, the landmark school law constitutional cases-Pierce $v$. Society of Sisters ${ }^{1}$ and Meyer $v$. Nebraska ${ }^{2}$-were couched in the same substantive due process terms as were the cases that declared invalid state attempts to regulate the economy. During this era, courts, reluctant to acknowledge the regulatory powers of either the state or the instrumentalities to which it delegated authority, also struck down school board regulations concerning such things as compulsory vaccinations, ${ }^{3}$ membership in secret societies, ${ }^{4}$ and penalties for accidentally damaging school property, ${ }^{5}$ on the grounds that such regulations went

* This Paper was originally presented in November, 1969, as a lecture to the School Solicitor's Association of Pennsylvania.

†Associate Professor of Law, University of Pennsylvania. A.B., 1959, LL.B., 1962, University of Pennsylvania. Member, Pennsylvania Bar.

1268 U.S. 510 (1925).

2262 U.S. 390 (1923).

3 See, e.g., Mathews v. Board of Educ., 127 Mich. 530, 86 N.W. 1036 (1901). Accord, Potts v. Breen, 167 I1l. 67, 47 N.E. 81 (1897) (health department regulation).

4 See Wright v. Board of Educ., 295 Mo. 466, 246 S.W. 43 (1922). But see Wilson v. Board of Educ., 233 Ill. 464, 84 N.E. 697 (1908); Wayland v. Board of School Directors, 43 Wash. 441, 86 P. 642 (1906).

5 See Holman v. School Trustees, 77 Mich. 605, 43 N.W. 996 (1889) ; State v. Vanderbilt, 116 Ind. 11,18 N.E. 266 (1888); Perkins v. Board of Directors, 56 Iowa 476, 9 N.W. 356 (1880). 
beyond the scope of the power delegated to school boards under state law.

From the end of this period (sometime in the 1930's) until very recently, intense judicial scrutiny and skepticism of governmental action gave way to great judicial deference to administrative and other governmental decision-making. We experienced the heyday of our faith in the administrative process and the judgment of professionals and specialists, a faith reflected in judicial attitudes toward school administrative decision-making. Judicial deference was reinforced in the school context by a specific faith in the quality of American education. Thus, school regulations were consistently upheld on the ground that they were not "clearly arbitrary and unreasonable," although courts never explored whether or not the rules performed a proper educational function. Moreover, even if a court did inquire into the purposes and objectives of the rule, it would invariably accept without question the school administration's conjectures about the dangers to which the educational process would have been exposed had the regulations in question not been adopted and enforced. ${ }^{7}$

Very recently, we have entered a third era in which the pendulum is swinging back toward our initial skepticism. The reasons for this swing are many. First, our former faith in expertise and the administrative process in general has diminished. Not only have we suffered many failures by agencies to accomplish their goals, but we have also seen that in many areas the work of the agency may even tend to destroy the humanity of the group which it seeks to help.

Second, that faith in American education which once reinforced a more general confidence in the administrative process has been replaced by growing doubts about the ability of public education to perform its function of educating our children. While the most notable failure of the system has been its inability to educate the black and the poor, there has also been questioning and doubt concerning the operations of public education in white middle-class suburbs. In part, these doubts grow out of the more general reexamination of societal

6 Board of Directors v. Green, 259 Iowa 1260, 1267, 147 N.W.2d 854, 858 (1967) ; see McLean Indep. School Dist. v. Andrews, 333 S.W.2d 886, 888-89 (Tex. Civ. App. 1960); State ex rel. Thompson v. Marion County Bd. of Educ., 202 Tenn. 29, 34, 302 S.W.2d 57, 59 (1957); Casey County Bd. of Educ. v. Luster, 282 S.W.2d 333, 334 (Ky. 1955).

7 See, e.g., Leonard v. School Comm., 349 Mass. 704, 212 N.E.2d 468 (1965); Fitzpatrick v. Board of Educ., 54 Misc. 2d 1085, 284 N.Y.S.2d 590 (Sup. Ct. 1967).

A notable exception in this era of great judicial deference to school administrators is the decision of the Supreme Court in West Virginia State Bd. of Educ. v. Barnette, 319 U.S. 624 (1943). Yet, even this case was preceded by a contrary decision only three years earlier in Minersville School Dist. v. Gobitis, 310 U.S. 586 (1940). Also, even when reading Barnette today, one is struck by how much this remarkable opinion was a reflection of the Court's strong antipathy to the then current supranationalism embodied in fascism. 
values and aims that we are currently undergoing. But they also reflect the increased sophistication and intellectual age of many students today.

Finally, since Brown v. Board of Education ${ }^{8}$ was decided in 1954, the courts have been heavily involved in matters concerning public education. It is not surprising that their involvement in segregation problems made the courts more responsive to other problems of public education. It is more than coincidence, for example, that a large number of the leading procedural due process cases concerning suspension or expulsion of students involve substantial racial elements. ${ }^{9}$ As stated above, these factors have led us into a new epoch of judicial involvement in public education. Without trying to be definitive, $I$ would like to suggest a few of the major trends in this new era.

First, there is a growing recognition that students cannot be regarded as merely passive vessels into which education is poured, but must, at least to a limited extent, be regarded as active participants in the educational process. To oversimplify, education can be divided, for analytical purposes, into two models: prescriptive and analytic. In the prescriptive model, information and accepted truths are furnished to a theoretically passive, absorbent student. The teacher's role is to convey these truths rather than to create new wisdom. Both teacher and student appear almost as automatons. Analytic education, however, signifies the examination of data and values in a way that involves the student and teacher as active participants in the search for truth. While these polar models represent only a theoretical paradigm that can never exist in pure form, we have traditionally conceived of precollege public education as essentially prescriptive, and college and postgraduate studies as analytic.

Now, however, one senses that the courts, along with the rest of society, see these lines (which were never clearly drawn to begin with) becoming more and more blurred. With greater numbers of people going to college today than ever before, with more and more college remedial programs available for the poor and disadvantaged, and with the creation of new institutions such as junior and community colleges, many colleges may be moving somewhat from the analytic model, once envisioned as the ideal for higher education, toward the prescriptive secondary school model.

Paradoxically, and more important from the point of view of student "rights," a strong movement exists at the moment to make

8347 U.S. 483 (1954).

9 See, e.g., Dixon v. Alabama State Bd. of Educ., 294 F.2d 150 (5th Cir. 1961); Madera v. Board of Educ., 267 F. Supp. 356 (S.D.N.Y.), rev'd, 386 F.2d 778 (2d Cir. 1967), cert. denied, 390 U.S. 1028 (1968) (Spanish-speaking); cf. Kelley v. Metropolitan County Bd. of Educ., 293 F. Supp. 485 (M.D. Tenn. 1968). 
high schools more analytic. Many high school students today are intellectually more mature than their college counterparts of a generation ago. The influences of television and other mass media on the perspectives of even our very young children are pervasive. Possessed of heretofore unparallelled training and maturity, today's high school student may be dissatisfied with the traditional mode of public education.

Sympathetic concern for student unhappiness, as well as impatience with a primarily prescriptive model of high school education, finds judicial expression in cases like Tinker v. Des Moines Independent Community School District. ${ }^{10}$ As Mr. Justice Fortas stated for the Court:

In our system, students may not be regarded as closedcircuit recipients of only that which the State chooses to communicate. They may not be confined to the expression of those sentiments that are officially approved. ${ }^{11}$

Recognition of the necessity for public education to assume more of the characteristics of the analytic model is also apparent in the adoption of new and more permissive rules concerning student expression by such school districts as Philadelphia and New York.

The second major trend is no less paradoxical: while we have experienced a growing lack of faith in the current educational structure, at the same time our belief in the importance of public education to the students involved has increased. Both tendencies contribute to a growing judicial reluctance to accept long-term suspensions or expulsion as appropriate school sanctions. This reluctance exhibits itself both in cases requiring greater procedural safeguards for implementing such sanctions, and in decisions striking down substantive rules, the violation of which is punished by either a long-term suspension or expulsion. ${ }^{12}$

10393 U.S. 503 (1969).

$11 \mathrm{Id}$. at 511 . Although this Paper is concerned with student rights, it should be noted that the trend toward a more analytic secondary school situation might also affect the rights of teachers. The basic doctrines of teacher academic freedom have been developed at the college level. See Keyishian v. Board of Regents, 385 U.S. 589 (1967); Developments in the Laz-Academic Freedom, 81 HARv. L. Rev. 1045, 1065-84 (1968). Yet, although it managed to avoid the ultimate question, the Supreme Court in Epperson v. Arkansas, 393 U.S. 97, 104-05, 107, again through Mr. Justice Fortas, seemed not to see a distinction between higher and lower education, and pointedly hinted at the extension of teacher academic freedom into secondary school classrooms.

12 These cases can be divided into two groups: (1) those in which the underlying basis for the substantive rule is quite doubtful, and (2) ones in which the court clearly accepts the underlying rule but finds the penalty of long-term suspension or expulsion too drastic a sanction. For the first type, compare, e.g., Board of Educ. v. Bentley, 383 S.W.2d 677 (Ky. 1964); McLeod v. State ex rel. Colmer, 154 Miss. 468, 122 So. 737 (1929), with Board of Directors v. Green, 259 Iowa 1260, 147 N.W.2d 854 (1967); State ex rel. Baker v. Stevenson, 27 Ohio Op. 2d 223, 189 N.E.2d 181 (1962). An example of the second type is found in the recent case of Anderson v. Independent School Dist. No. 281, No. 656514 (Minn. Dist. Ct., Juv. Div., Feb. 18, 1969), currently on appeal to the Minnesota Supreme Court. In Anderson, the court accepted the validity of a school's no-smoking rule but struck down a long-term suspension for a second offense. 
Whether one characterizes attendance at a public school as a "right" or a "privilege," it is of great value to the student. In light of this country's general norm of universal public education, ${ }^{13}$ longterm suspension or expulsion must bear a heavy burden to justify subordinating the interest of the student by deviating from this norm. Indeed, the schools themselves agree with and contribute to this feeling. It is not surprising that judges, who have witnessed intensive school campaigns to convince drop-outs to return to school because of the crucial significance of education in our society, react unsympathetically to school action suspending or expelling students for minor infractions of school rules and to attempts by school administrators to deprive students of access to school without first affording them adequate procedural safeguards.

The third major trend, a growing recognition that students and their parents have rights of privacy that should not be unduly interfered with by the state or the school structure, is part of a general movement that affects many other areas of jurisprudence in addition to school law. Perhaps the trend can be best illustrated by comparing early judicial decisions regarding hair and dress regulations with more recent ones. The 1965 decision of the Massachusetts Supreme Court in Leonard v. School Committee ${ }^{14}$ is typical of what we can now call "early" decisions in this area. In upholding the indefinite suspension of a high school boy because his hair was too long, the court's conception of the role of the judiciary in reviewing decisions of school administrators was that:

[W] e need only perceive some rational basis for the rule requiring acceptable haircuts in order to sustain its validity. Conversely, only if convinced that the regulation of pupils' hair styles and lengths could have no reasonable connection with the successful operation of a public school could we hold otherwise. ${ }^{15}$

By awarding an almost absolute deference to the school administration, the court failed to demonstrate that it was at all aware of the countervailing factor that dress and appearance is an area of life ordinarily left to private decision-making. It therefore avoided the difficult question whether, under our total legal system, and the presumptions of the

13 See Goldstein, The Scope and Sources of School Board Authority to Regulate Student Conduct and Status: $A$ Nonconstitutional Analysis, 117 U. PA. L. REv. 373, 393-94 n.74 (1969).

14349 Mass. 704, 212 N.E.2d 468 (1965).

15 Id. at 709, 212 N.E.2d at 472. See also Ferrell v. Dallas Indep. School Dist., 261 F. Supp. 545, (N.D. Tex. 1966), aff'd, 392 F.2d 697 (5th Cir.) cert. denied, 393 U.S. 856 (1968) ; Davis v. Firment. 269 F. Supp. 524 (E.D. La. 1967) ; Akin v. Board of Educ., 262 Cal. App. 2d 161, 68 Cal. Rptr. 557 (1968). 
societal and governmental systems within which it exists, the interest of the school system outweighs that of the student and his parent in making private decisions regarding personal appearance. ${ }^{16}$

In contrast with early cases like Leonard are the ever-increasing number of recent cases, decided by both state and federal courts, that strike down school regulations restricting hair and dress choices of students and their parents. ${ }^{17}$ These recent cases, whether decided on constitutional grounds or based on an analysis of the state law power of school boards ${ }^{18}$ (which I believe is the better reasoning), are much more discriminating in their approach. Rather than merely comparing a regulation to some abstract quality of reasonableness or arbitrariness, current judicial scrutiny includes an examination of its asserted purpose and effect, the factual bases underlying this assertion, and the countervailing factors such as privacy and individual decision-making that are displaced if the rule is upheld. In essence, the courts not only are seeking to ask the hard questions that the Leonard case and other early decisions avoided, but are also striving to answer them by weighing all of the relevant factors in order to reach an optimal balance. In resolving each case and reaching this often delicate balance, the courts are heavily influenced by a growing general feeling that in our society, privacy and individuality need protection.

These hair and dress cases, as well as Tinker, also exhibit the final and most important trend discussed here: the increasing demand that school administration justify a regulation, not by conjecturing about the adverse consequences to the educational structure without the rule, but by presenting hard facts. Contrary to the beliefs of many people, the courts are not so much saying that the schools cannot act to achieve traditional aims-to prevent disruption, for example-but they are saying that they will no longer take an administrator's unsupported word that absent a given rule, regulation, or procedure, disruption will take place.

One example of the new judicial philosophy is Breen $v . K a h l^{19}$ in which a school district tried to support a restriction on long hair on

16 See Goldstein, supra note 13 , at $399-400,420-422$.

17 See, e.g., Richards v. Thurston, 304 F. Supp. 449 (D. Mass. 1969) ; Griffin v. Tatum, 300 F. Supp. 60 (M.D. Ala. 1969) ; Breen v. Kahl, 296 F. Supp. 702 (W.D. Wis.), aff'd, 38 U.S.L.W. 2332 (7th Cir., Dec. 3, 1969); Meyers v. Arcata Union High School Dist., - Cal. App. 2d - 75 "Cal. Rptr. 68 (1969); Cirker v. Yohe, No. 2108 (C.P. Chester Co., Pa. 1969). But see Crews v. Cloncs, 303 F. Supp. 1370 (S.D. Ind. 1969). See also In re Johnson, No. 8023 (N.Y. Comm. of Educ., July 25, 1969); In re Myers, No. 8021 (N.Y. Comm. of Educ., July 25, 1969).

Note that these recent hair and dress judicial decisions were foreshadowed by the 1967 decision of the State Board of Education of New Jersey, Pelletreau v. Board of Educ., N.J. Bd. of Educ., Sept. 6, 1967. See also, In re Dalrymple, 5 N.Y. ED. DEP'T REP. 113 (1966).

18 See Goldstein, supra note 13, at 376-77.

10296 F. Supp. 702 (W.D. Wis.), aff'd, 38 U.S.L.W. 2332 (7th Cir., Dec. 3, 1969). 
the usual ground that it would distract other students and thereby disrupt the school process. The district court faced the issue not by unquestioning deference to the "professional" judgment of the administrators, but by carefully examining the factual record for evidence of disruption, disorder, or distraction. It is not surprising that the court found it wanting. In the words of the court:

With respect to the "distraction" factor, the showing in this record consists of expressions of opinion by several educational administrators that an abnormal appearance of one student distracts others. There is no direct testimony that such distraction has occurred. There has been no offer of the results of any empirical studies on the subject by educators, psychologists, psychiatrists, or other experts. Even in the opinions which have been received in evidence, there has been no amplification with respect to what portion of the students are susceptible to such distraction, how frequently susceptible students are likely to be distracted for this reason, how quickly or slowly high school students accommodate to individual differences in appearance, or how the distraction actually manifests itself in terms of the behavior of the distracted students in various learning situations. From the testimony of the educational administrators, it appears that the absence of such amplification is not accidental; it arises from the absence of factual data which might provide the amplification. ${ }^{20}$

Similarly, the Supreme Court in Tinker rejected the school administration's "undifferentiated fear or apprehension of disturbance" as a basis for prohibiting the wearing of black armbands by students. ${ }^{21}$

Two corollaries to the demand that hard facts be presented if a school rule is to be upheld as necessary to prevent disruption deserve further mention. The first is a suggestion that the alleged disruption must be substantial. Because they are not totally removed from reality, judges know that the public school system tolerates many and varied disruptions during the course of a school year. It is not unusual for students to be dismissed from school early to go to football games, or to be sent from class to go to the lavatory, the principal's office, or to take a note to another teacher. They are constantly moving and talking in the halls while switching classes, going to lunch, and so forth. Furthermore, students occasionally leave school early for vacations and return late for no more significant reason than their parents' convenience. All these disruptions and more are commonly accepted by the school system. Thus, it is not surprising that a court questions the 
validity of a presentation in which the school administration portrays the school as an island of pristine calm and precision in which long hair, or the absence of a child on a demonstration day, is seriously disruptive. The challenge to education, as it has been traditionally recognized, is not to eliminate all disruptions, but to use them creatively.

The other side effect of the demand for hard facts may be more difficult for school administrators to accept. More and more, courts are refusing to allow schools to penalize a student for violating a school rule where the rationale for punishment is an assertion that the failure to so punish would make the principal or school board lose face, which would itself disrupt or impede appropriate school functions. As the district court stated in Breen:

The point made about discipline seems to be that the disciplinary powers of the school authorities will be diminished if this Board regulation is not upheld and these expulsions and threatened expulsions are not vindicated by the court.

Obviously the relationship of students, faculty, administrators, and school board will be affected in some degree by a judicial declaration of invalidity of a school board regulation. But if the regulation is fairly found to violate the Constitution, responsibility for these consequences rests with the agency which promulgated the regulation. So far as education of young people in obedience is concerned, it is important for them to appreciate the present vitality of our proud tradition that although we respect government in the exercise of its constitutional powers, we jealously guard our freedoms from its attempts to exercise unconstitutional powers.

. . There is a significant distinction between disruption which may be caused by the wearing of long hair, on the one hand, and disruption which may be caused by the very fact that a student has violated any Board rule, on the other. That disruption of the latter type may occur obviously affords no support for constitutionality of the regulation itself. ${ }^{22}$

To summarize briefly the importance of these developments for school officials and the attorneys who advise them, I believe that they signify and remind us of the need to adopt newer, more flexible responses to student requests for opportunities for expression. Rather than deny a student request because the proposal has never been tried before, administrators must attempt to grapple with a new idea in

22296 F. Supp. at 708 \& n.8. See also Griffin v. Tatum, 300 F. Supp. 60, 63 (M.D. Ala. 1969): "In this case, it was the school officials who created what Judge Tuttle . . accurately described as 'something of a tempest in a teapot' and it is they who must accept responsibility for the consequences." 
order to determine with some fairness whether it can be tried, or more important, whether it can be utilized to increase the efficacy of the educational process.

Confrontations should be avoided. Therefore, plans for change should be undertaken in advance of student demands; all levels of the school structure, including the teacher level, should be made aware of this need. It is probably too late to save a situation once an administrator has said no when he should not have. After that, the question shifts from the desirability and feasibility of the request to the desirability and feasibility of the administration backing down. It is clearly too late to save a situation once a school is in court with a weak case.

All of these developments make life much harder for school administrators. In the face of this new situation there is a danger of going to one of two extremes. The obvious danger of a school digging in its heels and fighting these trends has been discussed above. A less obvious but still real danger exists of drifting to the other extreme by adopting the attitude that since courts have "handcuffed" school administrators, the administrators must give up educational leadership in the field of student expression. What we must recognize is that freedom of student expression is not intended as, and should not be interpreted as, an encouragement of license. On the contrary, by freeing students from coercive school rules we will, or at least we intend to, establish a point at which free men begin to assume the selfresponsibility that is the essential function of education in this area. It is, of course, much easier to censor a school newspaper than to teach students the concepts of good taste and responsibility which obviate the need for censorship. Yet, this latter method must be the educational norm in a free society. It is, in the words of the Supreme Court, the "slow and easily neglected route" ${ }^{23}$ to which we are committed.

23 Board of Educ. v. Barnette, 319 U.S. 624, 631 (1943). The Court was here contrasting the quick but invalid route to instilling patriotism through use of a compulsory flag salute with the slower, harder, but better route of teaching about American society and its traditions. See also the statement of the then New York City Superintendent of Schools, Bernard E. Donovan, that "a program of education rather than punitive action" is the proper approach to hair and dress problems. N.Y. Times, Nov. 13,1966 , at 9 , col. 5 . 